\title{
Training needs assessment of rural women regarding health and nutrition practices in Bikaner district of Rajasthan
}

\author{
Suchitra and Neena Sareen
}

See end of the paper for authors' affiliations

\section{Suchitra}

Department of Extension

Education, Vivekananda Global

University, Jaipur (Rajasthan)

India

Email : suchi3mothsara@gmail.

com

Received: 22.09.2020; Revised: 02.11.2020; Accepted: 22.11 .2020

ABSTRACT : The present study was conducted in six panchayat samities out of which Bikaner panchayat samiti was selected. Out of thirty one Gram panchayat in Bikaner panchayat samiti four Gram panchayat were selected one village was selected on the basis of random sampling technique. Findings revealed that the result of training needs of rural women regarding health and nutrition practices showed that "Nutrition for children 0 to 6 years", 'Nutritional Recipes', 'Balanced diet', Family planning', 'Care of pregnant and lactating mother', 'Child care' were perceived by the rural women as the most important training areas for improved nutritional and health status whereas, 'Low cost recipes', and 'Function of food', 'Environmental sanitation', were perceived as the somewhat important training area by the rural women.The variables namely "family income, education, mass media contact, extension contact were positively and significantly correlated with training needs of the rural women about health and nutritional practices at 1 per cent level of probability. Whereas, age, training participation had negative significant relationship with training needs of the rural women about health and nutritional practices

KEY WORDS: Training needs assessment, Rural women, Health, Nutrition

- HOW TO CITE THIS PAPER : Suchitra and Sareen, Neena (2020). Training needs assessment of rural women regarding health and nutrition practices in Bikaner District of Rajasthan. Asian J. Home Sci., 15 (2) : 318-324, DOI: 10.15740/HAS/AJHS/15.2/318-324. Copyright@ 2020: Hind Agri-Horticultural Society. 